\title{
Effect of the Adoption of IFRS on the Information Relevance of Accounting Profits in Brazil
}

Mateus Alexandre Costa dos Santos

PhD candidate, Multi-institutional and Inter-regional Graduate Program in Accounting Sciences, University of Brasília, Federal University of Paraíba, Federal University of Rio Grande do Norte E-mail: profmateusacs@hotmail.com

Paulo Roberto Nóbrega Cavalcante

$\mathrm{PhD}$, Comptrollership and Accounting, Federal University of Paraíba

E-mail: paulocavalcante@ccsa.ufpb.br

Received on 1.7.2013 - Desk Acceptance on 1.18.2013 - 4th version accepted on 8.11.2014.

\begin{abstract}
This study aimed to assess the effect of adopting the International Financial Reporting Standards (IFRS) in Brazil on the information relevance of accounting profits of publicly. traded companies. International studies have shown that the adoption of IFRS improves the quality of accounting information compared with domestic accounting standards, Concurrent evidence is sparse in Brazil. Information relevance is understood herein as a multidimensional attribute that is closely related to the quality and usefulness of the information conveyed by accounting profits. The associative capacity and information timeliness of accounting profits in relation to share prices were examined. Furthermore, the level of conditional conservatism present in accounting profits was also analyzed because according to Basu (1997), this aspect is related to timeliness. The study used pooled regressions and panel data models to analyze the quarterly accounting profits of 246 companies between the first quarter of 1999 and the first quarter of 2013, resulting in 9,558 quarter-company observations. The results indicated that the adoption of IFRS in Brazil (1) increased the associative capacity of accounting profits; (2) reduced information timeliness to non-significant levels; and (3) had no effect on conditional conservatism. The joint analysis of the empirical evidence from the present study conclusively precludes stating that the adoption of IFRS in Brazil contributed to an increase the information relevance of accounting profits of publicly traded companies.
\end{abstract}

Keywords: IFRS in Brazil; associative capacity; information timeliness; conservatism. 


\section{INTRODUCTION}

One of the most important motivations for the adoption of the International Financial Reporting Standards (IFRS) is to increase the comparability of accounting information among countries. Thus, the IFRS seek to establish a common language for the markets and a favorable environment for smoother capital flows (Ball, 2006; Lima, 2010; Niyama, 2007).

Thus, the concepts and the recognition, measurement and disclosure criteria established by the IFRS presumably provide higher information quality, which in turn affects the usefulness of the accounting information generated (Barth, Landsman, \& Lang, 2008; Leuz \& Wysock, 2008). International studies, particularly in European countries, have examined this topic and have advanced the understanding of the effects of the adoption of IFRS on accounting information itself and on the users of that information (Ashbaugh \& Pincus, 2001; Barth et al., 2008; Garanina \& Kormiltseva, 2014; Kargin, 2013; Jarva \& Lantto, 2012; Landsman, Maydew, \& Thornock, 2012; Soderstrom \& Sun, 2007).

Given the convergence process recently experienced in Brazil, the assessment of the effects of the adoption of IFRS on the accounting information disclosed by Brazilian companies is currently an important issue. Some studies have accordingly been conducted under different viewpoints, although the results are still divergent (Costa, 2012; Lima, 2010; Macedo, Machado, Machado, \& Mendonça, 2013; Oliveira \& Lemes, 2011; Rodrigues, 2012; Santos, Lima, Freitas, \& Lima, 2011). The present study falls within this context and aims to assess the effect of the adoption of IFRS on the information relevance of net profits in the Brazilian scenario, thus contributing toward a greater understanding of the subject.

Information relevance is understood as a multidimensional attribute that is closely related to the usefulness of the information provided to the user. This attribute comprises: (i) the associative capacity between the accounting information, in this case, the profit, and the market value of the company, commonly known as value relevance (Barth, Beaver, \& Landsman, 2001; Ball, 2006); (ii) the timeliness of the information, that is, its capacity to simultaneously represent and express events conside- red important by market participants when pricing shares (Ball, 2006; Basu, 1997; Santos \& Lustosa, 2010); and (iii) the information content, which in broad terms refers to the impact on share prices caused by the disclosure of accounting information (Landsman et al., 2012).

This study examined the associative capacity and the information timeliness of accounting profits. However, in addition to these two aspects, studies have suggested that other factors, for example, conservatism, the existence of few opportunities for earnings management, and profit persistence, may capture key dimensions of the quality of a company's accounting information (Ball, 2006; Leuz \& Wysock, 2008). Thus, these factors may also contribute to information relevance. Therefore, this study also sought to assess the effects of the adoption of IFRS on the level of conditional conservatism present in accounting profits because it is a key characteristic related to information timeliness.

Thus, the present study explored the following research question:

What are the effects of the adoption of IFRS on the information relevance of accounting information in Brazil as measured by the associative capacity, information timeliness, and conservatism of the accounting profits of publicly traded companies?

Importantly, the analysis of this issue excludes an assessment of the information quality generated when adopting IFRS or whether such standards are higher than domestic standards because no comparison whatsoever can be established between the criteria prescribed by those regulations. Furthermore, the analysis overlooks aspects regarding how this information should be by aiming to instead assess how useful it is (or appears to be) from the viewpoint of participants in the Brazilian stock market.

This article is divided into five sections, including this introduction. Section 2 provides the theoretical framework, outlines some aspects of the adoption of the convergence process in Brazil, and examines some previous studies. Subsequently, section 3 describes the methods employed, including the hypotheses and models. Section 4 outlines and discusses the results, and section 5 concludes.

\section{THEORETICAL FRAMEWORK}

\subsection{A Brief Comment on the Adoption of IFRS in Brazil}

The IFRS presumably have higher quality than most domestic accounting norms or standards, and studies have reported results accordingly (Ashbaugh \& Pincus, 2001; Barth et al., 2008; Costa, 2012; Landsman et al., 2012; Lima, 2010).

When compared with the domestic standards of environments with strong legal, political, and taxation im- pacts, the IFRS: (i) better reflect the economic substance of events; (ii) are more timely; (iii) generate more informative profits; (iv) provide more useful balance sheets; and (v) reduce the manipulation of accounting information (Ball, 2006).

However, this quality does not per se guarantee that the adoption of IFRS will increase the relevance of accounting information. Numerous studies indicate that accounting is the product of legal, economic, political, and 
institutional factors that affect the financial disclosure incentives of companies in each country, factors that also affect how the IFRS are implemented and assimilated in each country, generating distinct economic consequences (Soderstrom and Sun, 2007; Niyama 2007; Leuz and Wysock, 2008; Lima, 2010).

Brazil has a codified and extremely legalistic legal system (code law). Before the convergence, accounting standards were strongly affected by legal directives, especially by tax laws and regulations from government agencies, including the Central Bank of Brazil (Banco Central do Brasil - BC) and the Brazilian Securities Commission (Comissão de Valores Mobiliários - CVM) (Dantas, Rodrigues, Niyama, \& Mendes, 2010; Niyama, 2007).

Professional accounting bodies or institutions representative of the profession had weak political influence in the process of establishing accounting procedures (Niyama, 2007). Accordingly, accounting information was ruled by objectivity and verifiability, and the government was the main user, thus providing low relevance for other users, especially participants in the stock market.

The main landmark in Brazil's process of convergence with international accounting standards was the enactment of Law No. 11.638/2007, which amended Laws No. 6.404/1976 (Corporate Law - Lei das Sociedades por Ações, S.A.) and No. 6.385/1976 to effect this standards conversion in the national legal system. This process has been ongoing since the 1990s and included, for example, institutional efforts by the CVM to improve Brazilian accounting standards through the incorporation of standard precepts of the International Accounting Standards Board (IASB) (Dantas, Rodrigues, Niyama, and Mendes, 2010).

The adoption of the IFRS arguably occurred in two stages in the case of publicly traded companies because their adoption only became mandatory in 2010 pursuant to CVM Instruction No. 457/2007, amended by CVM Instruction No. 485/2010. Thus, a transition period encompassed the years 2008 and 2009.

The implementation of the Transition Tax Regime (Regime Tributário de Transição, RTT), established by Provisional Measure No. 449/2008 (subsequently enacted into Law No. 11.941/2009) and extinguished by Provisional Measure No. 427/2013, enabled one of the flagship issues in the Brazilian convergence process: tax neutrality.

Another positive factor was the level of development experienced by the Brazilian stock market in recent years. The Corporate Law (Lei das S.A.) reformulation in 2001, price stability, the liberalization of the stock market, and the creation of different levels of corporate governance and the new market were significant events that contributed to this development (Lima, 2010).

Thus, given Brazil's institutional characteristics before and after the convergence, the mandatory and legally binding adoption of IFRS will likely allow at least greater independence for financial reporting. Therefore, greater relevance of accounting information for market partici- pants may be observed if the IFRS are indeed better than the domestic standards.

\subsection{Previous Studies}

Previous studies have mostly indicated that the adoption of IFRS improves accounting information quality (Soderstrom \& Sun, 2007). However, different results concerning the information relevance of accounting profits, as examined herein, have been observed, especially regarding value relevance, which is one of the attributes that has been extensively examined by prior studies.

For example, Barth, Landsman, and Lang (2008) examined 21 countries and found that companies that adopted the IFRS showed a timelier recognition of losses and a higher association between share prices and accounting profits and net worth (value relevance).

In Greece, Karampinis and Hevas (2009) found that the mandatory adoption of the IFRS positively affected the value relevance of accounting profits and book value of equity, albeit only at the level of consolidated statements.

Conversely, Li (2010) found that European Union companies that began the mandatory adoption of IFRS experienced a reduction of approximately $47 \%$ in their cost of capital. According to the author, increased financial reporting and improved intercompany information comparability accounted for this reduction.

Landsman, Maydew, and Thornock (2012) found increased information content of accounting profits in countries that adopted the IFRS compared with countries that maintained domestic accounting standards. This result was found at the level of both countries and companies. The study covered the period from 2002 to 2007 and analyzed 16 countries that had adopted the IFRS and 11 that had not, including Brazil.

Also at a multi-jurisdictional level, Ahmed, Chalmers, and Khlif (2013) observed a mostly increased association (value relevance) between accounting profits and share prices, although they noted that the level of association shown by book value of equity did not vary in the post-IFRS period. These results remained unchanged even after controlling for the effects of institutional factors in the analyzed countries.

Conversely, different results were reported by Callao, Jarne, and Laínez (2007), whose evidence suggests that the adoption of IFRS in Spain failed to improve the relevance of financial reports for participants in the local stock market. The study found that differences between the accounting value and the market value of Spanish companies increased with the adoption of IFRS.

Similarly, Hung and Subramanyam (2007) noted that in Germany, total assets and book value of equity as well as book value of equity and net profit variations are greater under the IFRS and that net worth, compared with net profits, plays a more important role in the evaluation of companies and has a greater association with share prices. The main finding of that study was the change caused by the IFRS on the accounting information dynamics for some of the users. 
Accordingly, Clarkson, Hanna, Richardson, and Thompson (2011) gathered evidence suggesting that adopting the IFRS failed to improve the quality of financial reporting in Europe and Australia. The evaluation conducted in that study was based on an assessment of associations between share prices, accounting profits, and book value of equity from the viewpoint of the IFRS in relation to both domestic standards and to the legal system of the countries analyzed (customary or consuetudinary).

Conversely, Klimczak (2011) found no evidence that the mandatory adoption of IFRS in Poland affected the information content or the value relevance of accounting profits of Polish companies.

In turn, Jarva and Lantto (2012), when analyzing the IFRS vis-à-vis Finnish accounting standards, noted that profits calculated in accordance with the IFRS are less timely, although they marginally provide a higher predictive capability of future cash flows. Furthermore, the authors noted that assets and liabilities under those standards have a lower association with share prices. One of the reasons suggested for the results was that Finland already had high-quality accounting standards.

Conversely, Kargin (2013) analyzed the effects of the adoption of IFRS in Turkey and found evidence indicating that the adoption of these standards failed to improve the level of association between accounting profits and share prices. Conversely, the results showed that book value of equity was more relevant post-IFRS. According to the author, the application of IFRS tends to bring the book value of equity of Turkish companies closer to their market value, which could account for the result.

Garanina and Kormiltseva (2014) observed similar results in Russia. The authors found no evidence of increased value relevance of financial reporting resulting from the adoption of IFRS. The authors argued that the results may be caused by institutional differences between domestic standards and the IFRS.

The research landscape regarding Brazil is no different from what has been observed internationally. The studies conducted thus far also show conflicting results for diverse aspects of accounting information attributes.

Lima (2010) examined the effect of adopting the IFRS in 2008 and 2009 on information content and the relevance of accounting profits. No evidence of abnormal reactions of share prices in response to the disclosure of accounting profits post-IFRS was found. However, the results suggested that adopting those standards improved the information relevance of accounting profits.

Conversely, Santos, Lima, Freitas, and Lima (2011), when using the model by Basu (1997) and an adapted version of this model, found no evidence that adopting the IFRS affected the accounting conservatism of accounting profits of companies listed on the BM\&FBovespa Securities, Commodities, and Futures Exchange.

Costa (2012) found evidence that a decrease in financial and tax compliance occurred in 2009 and 2010 and that after IFRS adoption, the response coefficients of accounting profits were significant, which suggests an increased timeliness of that measure according to the author. However, in contrast to that conclusion, an association between post-convergence accounting profits and stock returns (value relevance) was observed by Lima (2010).

In turn, Rodrigues (2012) found that the adoption of IFRS in Brazil did not increase conditional conservatism, partly corroborating Santos et al. (2011), or affected the associative capacity of accounting profits (value relevance), thus contradicting the results of Lima (2010) and Costa (2012).

In contrast to Rodrigues (2012), Macedo, Machado, Machado, and Mendonça (2013) found that IFRS adoption increased the associative capacity (information capacity) of net profits, conferring them greater explanatory power. According to the authors, the fact that the economic reality of companies could be more faithfully depicted under the IFRS accounted for that improvement. However, the results failed to show the existence of effects on the associative capacity of book value of equity.

It is important to note that the differences observed in the prior studies should primarily be analyzed by considering the legal, economic, political, and institutional differences existing between countries because each adoption process represents a unique experience.

However, the methodological differences between the studies concerning the Brazilian environment gain relevance in the analysis of results, especially regarding the model and the econometric method used and the longitudinal and cross-sectional sample size.

\section{METHODS}

\subsection{Hypotheses}

The literature has shown that the IFRS incorporate a higher level of quality compared with most domestic regulations, with few exceptions. Accordingly, the present study aims to assess the effects of the mandatory adoption of the IFRS on the information relevance of accounting profits for participants in the Brazilian stock market. The following research hypotheses are tested for this purpose: H1: The adoption of the IFRS in Brazil increased the associative capacity of accounting profits in relation to share prices. $\mathrm{H} 2$ : The adoption of the IFRS in Brazil increased the information timeliness of accounting profits.

H3: The adoption of the IFRS in Brazil increased the conservatism level of accounting profits. 


\subsection{Study Sample}

Publicly traded Brazilian companies were the study object. Only those companies active on $07 / 18 / 2013$ according to the Economática ${ }^{\circledR}$ database were analyzed. Financial firms were excluded from the sample because they are subject to BC regulation. Data were analyzed on a quarterly basis from the $1^{\text {st }}$ quarter of 1999 to the $1^{\text {st }}$ quarter of 2013.

Preferred shares were analyzed when possible, given their greater liquidity. Share prices were adjusted for dividends according to the criterion used by Economática ${ }^{\circledR}$.

The accounting variables used were net profit per share (NPPS) and book value of equity per share (BVEPS), which was used as a control. These data were gathered from individual accounting statements. When assessing information timeliness and conservatism, these variables were deflated by the share price at beginning of the period $\left(p_{t-1}\right)$ to control for possible heteroscedasticity and maintain similarity with Basu (1997). Furthermore, outliers of $R_{i t}, \mathrm{NPPS}_{i t}$ (associative capacity), and $N P P S_{i t}$

$p_{t-1}$ (timeliness/conservatism) were excluded from the analysis; thus, values between the first and last percentiles were included.

Considering the selection criteria, data availability, and the adjustments performed, the final sample formed an unbalanced panel with 9,558 quarterly observations distributed among 246 companies.

\subsection{Models}

Pooled regressions and panel data were used. The criterion for the adoption of the method was a joint analysis of parameter stability using the Chow test and parameter variance using the test for differing group intercepts (DGI) and the Hausman test.

The null hypothesis of the Chow test is the absence of structural failure in the estimates. It is suitable when assessing the relevance of estimates using pooled regression. Conversely, DGI tests whether the cross-sectional units have a common intercept. The rejection of this hypothesis suggests that the fixed effects model is appropriate. Finally, the null hypothesis of the Hausman test is the consistency of estimates using Generalized Least Squares, in other words, estimates using the random effects model are appropriate in contrast to those performed using the fixed effects model.

Robust estimators were used in the estimations performed using the fixed effects model to mitigate possible issues of heteroscedasticity and autocorrelation of residuals, as proposed by Arellano (2003).

The associative capacity of accounting profits and share prices was the first functional relationship examined. Return models were used for this task.

Considering the statistical method used (panel data) and the pattern of the data series analyzed, the viable alternative to mitigate the occurrence of a possible scale effect (response coefficient bias and heteroscedasticity, among others) according to the tests performed (pricing model, deflation per $p_{\mathrm{t}-1}$ ) was the use of an exogenous scale, in this case, BVEPS ${ }_{i t}$, which was used as a control.

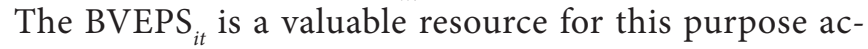
cording to Barth and Kallapur (1996), Barth and Clinch (2009), and Gil-Alana, Iniguez-Sanchez, and Lopez-Espinosa (2011).

The econometric models used to assess the associative capacity of accounting profits are shown below ${ }^{1}$ :

$$
\begin{gathered}
R_{i t}=\beta_{0}+\beta_{1} N P P S_{i t}+\beta_{2} B V E P S_{i t}+\varepsilon_{i t} \\
R_{i t}=\beta_{0}+\beta_{1} N P P S_{i t}+\beta_{2} B V E P S_{i t}+\delta_{1} D_{i t}^{I F R S}+\delta_{2} D_{i t}^{I F R S} \times N P P S_{i t}+\varepsilon_{i t} \\
R_{i t}=\beta_{0}+\beta_{1} N P P S_{i t}+\beta_{2} B V E P S_{i t}+\sum_{\tau=1}^{6} \delta_{\tau} D_{i t}^{2007+\tau}+\sum_{\tau=1}^{6}\left(\delta_{6+\tau} D_{i t}^{2007+\tau} \times N P P S_{i t}\right)+\varepsilon_{i t}
\end{gathered}
$$

where

$R_{i t}=$ Return of company $i$ in quarter $t$

$\mathrm{NPPS}_{i t}=$ Net profit per share of company $i$ in quarter $t$;

BVEPS $_{i t}=$ Book value of equity per share of company $i$ in quarter $t$;

$D_{i t}^{I F R S}=$ Dummy variable, $D_{i t}^{I F R S}=1$ if $t$ is after 2007;

$D_{i t}^{2008} \ldots D_{i t}^{2013}=$ Dummy variables, $D_{i t}^{2008} \ldots D_{i t}^{2013}=1$ if $t$ is equal to the specified year; $\beta$ 's and $\delta$ 's = model parameters;

$\varepsilon_{i t}=$ error term of the models.

The existence of a significant association between accounting profits and share prices will result in the identification of a significant and positive $\beta_{1}$. However, if the adoption of IFRS increased this capacity, the $\delta_{1}$ and $\delta_{2}$ coefficients in Model (2) and $\delta_{1}$ to $\delta_{10}$ in Model (3) are expected to be positive and show some level of significance.

The pattern of occurrence of structural breaks throu-

The estimations performed using the traditional pricing $\left(p_{i, t}=\beta_{0}+\beta_{1} N P P S_{i, t}+\varepsilon_{i, t}\right)$ or $\left(p_{i, t}=\beta_{0}+\beta_{1} N P P S_{i, t}+\beta_{2} B V E P S_{i, t}+\varepsilon_{i, t}\right)$ and return $\left(\frac{p_{i, t}}{p_{i, t-1}}=\beta_{0}+\beta_{1} \frac{N P P S_{i, t}}{p_{i, t-1}}+\varepsilon_{i, t}\right)$ or $\left.\frac{p_{i, t}}{p_{i, t-1}}=\beta_{0}+\beta_{1} \frac{N P P S_{i, t}}{p_{i, t-1}}+\beta_{2} \frac{B V E P S_{i, t}}{p_{i, t-1}}+\varepsilon_{i, t}\right)$ models showed no satisfactory results. For example, the pricing model showed an $R^{2}$ higher than 0.75 , which creates doubts regarding its correct fit because the variable price showed a non-stationary pattern in most of the data sets analyzed. Therefore, the return model was analyzed despite the use of panel estimates. However, in its traditional specification, this model created multicollinearity issues and contradictory results regarding the panel model definition to be used. These problems were overcome using the natural logarithm to calculate the return. 
ghout the entire period (from 1/1999 to 1/2013) was also analyzed for all of the models above. The Chow test was used to measure these occurrences.
Models (4), (5), and (6), which were used for timeliness and are based on Beaver, Lambert, and Morse (1980), are shown below:

$$
\begin{gathered}
\frac{N P P S_{i t}}{p_{t-1}}=\beta_{0}+\beta_{1} R_{i t}+\varepsilon_{i t} \\
\frac{N P P S_{i t}}{p_{t-1}}=\beta_{0}+\beta_{1} R_{i t}+\delta_{1} D_{i t}^{I F R S}+\delta_{2} D_{i t}^{I F R S} \times R_{i t}+\varepsilon_{i t} \\
\frac{N P P S_{i t}}{p_{t-1}}=\beta_{0}+\beta_{1} R_{i t}+\sum_{\tau=1}^{6} \delta_{\tau} D_{i t}^{2007+\tau}+\sum_{\tau=1}^{6}\left(\delta_{6+\tau} D_{i t}^{2007+\tau} \times R_{i t}\right)+\varepsilon_{i t}
\end{gathered}
$$

where $p_{\mathrm{t}-1}=$ is the share price measured at the end of the previous quarter $(t-1)$.

The coefficient $\beta_{1}$ represents the overall timeliness of accounting profits, whereas the coefficients $\delta_{1}$ and $\delta_{2}$ in Model (5) and $\delta_{1}$ to $\delta_{10}$ in Model (6) are related to information timeliness resulting from the adoption of IFRS.
Those coefficients will tend to be positive and significant if the standards render the accounting profits timelier.

Finally, conservatism level was measured using the models proposed by Basu (1997), Model (7); Santos et al. (2011), Model (8); and Model (9), which aims to assess the annual impact post-IFRS:

$$
\begin{gathered}
\frac{N P P S_{i t}}{p_{t-1}}=\beta_{0}+\beta_{1} R_{i t}+\delta_{1} D R_{i t}+\delta_{2} D R_{i t} \times R_{i t}+\varepsilon_{i t} \\
\frac{N P P S_{i t}}{p_{t-1}}=\beta_{0}+\beta_{1} R_{i t}+\delta_{1} D R_{i t}+\delta_{2} D R_{i t} \times R_{i t}+\delta_{3} D_{i t}^{I F R S} \times D R_{i t}+ \\
\delta_{4} D_{i t}^{I F R S} \times D R_{i t} \times R_{i t}+\varepsilon_{i t} \\
\frac{N P P S_{i t}}{p_{t-1}}=\beta_{0}+\beta_{1} R_{i t}+\delta_{1} D R_{i t}+\delta_{2} D R_{i t} \times R_{i t}+\sum_{\tau=1}^{6}\left(\delta_{2+\tau} D_{i t}^{2007+\tau} \times D R_{i t}\right)+ \\
\sum_{\tau=1}^{6}\left(\delta_{8+\tau} D_{i t}^{2007+\tau} \times D R_{i t} \times R_{i t}\right)+\varepsilon_{i t}
\end{gathered}
$$

where $D R_{i t}=1$ if $R_{i t}<0$.

The coefficients $\delta_{1}$ and $\delta_{2}$ represent the conditional conservatism of accounting profits, while coefficients $\delta_{3}$ and $\delta_{4}$ in Model (8) and $\delta_{3}$ to $\delta_{12}$ in Model (9) express the effects of adopting the IFRS on conservatism. Changes in the conservatism level will result in the significance of those coefficients.

Four estimations were performed using Models (1), (4), and (7) according to a segregation of the time period analyzed: (i) from the $1^{\text {st }}$ quarter/1999 to the $1^{\text {st }}$ quarter/2013 - total period; (ii) from the $1^{\text {st }}$ quarter/1999 to the $4^{\text {th }}$ quarter/2007 - pre-IFRS; (iii) from the $1^{\text {st }}$ quarter/2008 to the $4^{\text {th }}$ quarter/2009 - transition period; and (iv) from the $1^{\text {st }}$ quarter/2010 to the $1^{\text {st }}$ quarter/2013 - post-IFRS. The full adoption of IFRS began in 2010 pursuant to CVM Instruction No. 457/2007, amended by CVM Instruction No. 485/2010, although Law No.11.638/2007 was in effect beginning on $01 / 01 / 2008$, which explains this segregation.

\section{RESULTS}

4.1 Associative Capacity of Accounting Profits

Models (1), (2), and (3) were estimated in this sta- ge. Initially, Model (1) was estimated based on the entire period, and the other time periods were analyzed subse- 
quently. The results are shown in Table 1.

Regarding the total period, the NPPS ${ }_{i t}$ was highly significant and had the predicted sign for the proposed relationship. The model has a satisfactory fit and average explanatory power for this relationship.

Table 1

Model (1) Results - Associative Capacity

\begin{tabular}{|c|c|c|c|c|c|c|c|c|}
\hline \multicolumn{9}{|c|}{ Model (1): $R_{i t}=\beta_{0}+\beta_{1} N P P S_{i t}+\beta_{2} B V E P S_{i t}+\varepsilon_{i t}$} \\
\hline \multirow{2}{*}{ Period } & \multicolumn{2}{|c|}{$1 / 1999-1 / 2013$} & \multicolumn{2}{|c|}{$1 / 1999-4 / 2007$} & \multicolumn{2}{|c|}{$1 / 2008-4 / 2009$} & \multicolumn{2}{|c|}{$1 / 2010-1 / 2012$} \\
\hline & \multicolumn{2}{|c|}{ Total Period } & \multicolumn{2}{|c|}{ Pre-IFRS } & \multicolumn{2}{|c|}{ Transition } & \multicolumn{2}{|c|}{ Post-IFRS } \\
\hline \multirow[t]{2}{*}{ Panel Model } & \multicolumn{2}{|c|}{ Random Effects } & \multicolumn{2}{|c|}{ Random Effects } & \multicolumn{2}{|c|}{ Random Effects } & \multicolumn{2}{|c|}{ Fixed Effects } \\
\hline & Coeff. & $t$ Test & Coeff. & $t$ Test & Coeff. & $t$ Test & Coeff. & $t$ Test \\
\hline Intercept & 0.0186 & $7.0310^{* * *}$ & 0.0503 & $9.5341^{* * *}$ & -0.0110 & -1.6109 & -0.0248 & $-4.8378^{* * *}$ \\
\hline $\mathrm{NPPS}_{i t}$ & 0.0078 & $5.5537^{* * *}$ & 0.0057 & $3.0557^{* * *}$ & 0.0147 & $3.1676^{* * *}$ & 0.0095 & $2.2663^{* *}$ \\
\hline BVEPS $_{i t}$ & -0.0001 & -1.1636 & -0.0001 & -1.6036 & -0.0001 & -1.0193 & 0.0005 & 1.5073 \\
\hline$R^{2}$ (adj.) & \multicolumn{2}{|c|}{$0.0032(0.0030)$} & \multicolumn{2}{|c|}{$0.0031(0.0027)$} & \multicolumn{2}{|c|}{$0.0057(0.0046)$} & \multicolumn{2}{|c|}{$0.1255(0.0455)$} \\
\hline$F$ Test & \multicolumn{2}{|c|}{$15.4724^{* * *}$} & \multicolumn{2}{|c|}{$7.6917^{* * *}$} & \multicolumn{2}{|c|}{$5.0484^{* * *}$} & \multicolumn{2}{|c|}{$1.5697^{* * *}$} \\
\hline $\begin{array}{l}\text { Chow } \\
\text { (obs.) }\end{array}$ & \multicolumn{2}{|c|}{$\begin{array}{c}70.6412^{* * *} \\
(4.545)\end{array}$} & \multicolumn{2}{|c|}{$\begin{array}{c}16.0651^{* * * *} \\
(1.994)\end{array}$} & \multicolumn{2}{|c|}{$\begin{array}{c}226.5940^{* * *} \\
(1.079)\end{array}$} & \multicolumn{2}{|c|}{$\begin{array}{c}18.2122^{* * *} \\
(896)\end{array}$} \\
\hline DGI & \multicolumn{2}{|c|}{1.0735} & \multicolumn{2}{|c|}{1.0289} & \multicolumn{2}{|c|}{0.4227} & \multicolumn{2}{|c|}{$1.4491^{* * *}$} \\
\hline Hausman & \multicolumn{2}{|c|}{0.4243} & \multicolumn{2}{|c|}{2.1544} & \multicolumn{2}{|c|}{4.0955} & \multicolumn{2}{|c|}{$6.12463^{* * *}$} \\
\hline No. Obs & \multicolumn{2}{|c|}{9.558} & \multicolumn{2}{|c|}{4.932} & \multicolumn{2}{|c|}{1.749} & 2.8 & \\
\hline
\end{tabular}

$R_{i t}$ is the return of the $i$-th share in quarter $t$, calculated logarithmically. NPPS ${ }_{i t}$ represents the net profit of the exercise per share of the $i$-th company in quarter $t$. BVEPS is the book value os equity per share of the $i$-th company in quarter $t$. In the Chow test, (obs.) represents the observation where the greatest magnitude was identified. The presence of multicollinearity was not detected. Variance inflation factors $(V I F s)<2$.

$*, * *$, and ${ }^{* * *}$ represent significance at $10 \%, 5 \%$, and $1 \%$, respectively.

Although over the entire period structural breaks were observed both before and after adopting the IFRS, the most significant occurrence (Chow test $=$ $70.6412^{* * *}$ ) was observed in the 3 rd quarter of 2007 , a period prior to, albeit very close to the adoption of IFRS. Figure 1 shows this pattern.

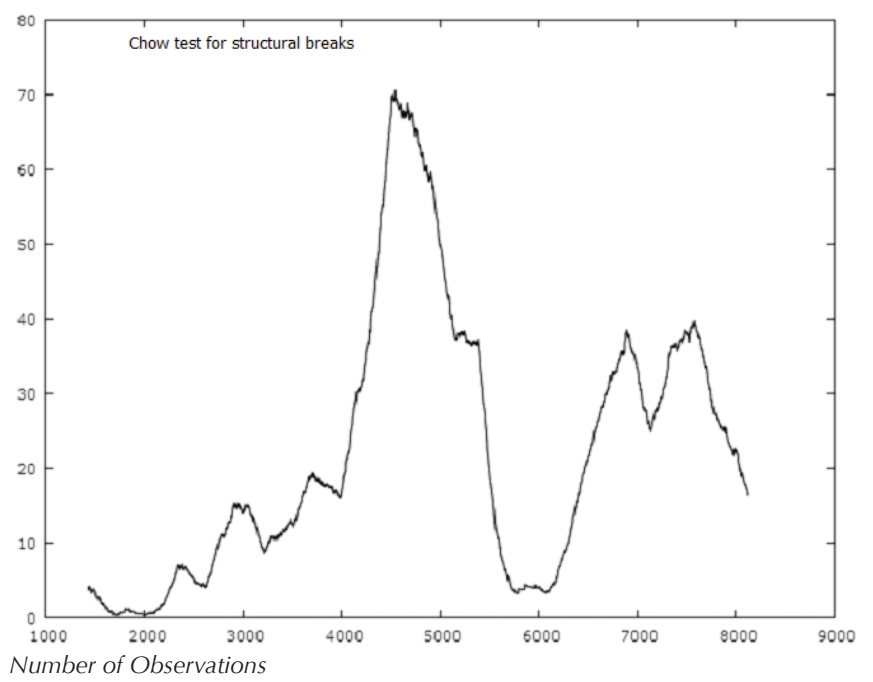

Figure 1 Chow Test Pattern - Model (1) Estimation for the Total Period

The results from the estimations of the pre-IFRS, transition, and post-IFRS periods indicated an improved association between NPPS ${ }_{i t}$ and $R_{i t}$ starting in the transition period. Although the NPPS ${ }_{i t}$ coefficient was positive for the entire period analyzed, as predicted, this coefficient had the smallest magnitude (0.0057) in the pre-IFRS period, and the model also had the smallest adjusted $\mathrm{R}^{2}$. Combined, these figures indicate an associative capacity of NPPS ${ }_{i t}$ in the pre-IFRS period that was lower than those observed in the following periods.

Conversely, in the transition period, the $\mathrm{NPPS}_{i t}$ coefficient became highly significant, and its magnitude increased from 0.0057 to 0.0147 . These results indicate that the associative capacity of NPPS ${ }_{i t}$ increased significantly in the transition period. This finding is confirmed by the increase in the adjusted $\mathrm{R}^{2}$, although this statistic had a low magnitude.

The indication of existing fixed effects in the post-IFRS period is the first striking aspect in the data panel. This result suggests the existence of idiosyncratic cross-sectional components, which is puzzling when compared with other periods because all companies mandatorily began adopting the IFRS in 2010 .

A decrease in the magnitude and significance of the NPPS $_{i t}$ coefficient is also observed. However, the statistical significance of this relationship was preserved. Moreover, the explanatory power of the model increased significantly, as shown by the increase in adjusted $\mathrm{R}^{2}$ from 0.0046 to 0.0455 .

The effects of adopting the IFRS on the associative capacity of accounting profits were assessed using Model (2) and the dummy variables indicative of the term of those standards. Table 2 shows the results. 
Table 2 Model (2) Results - Associative Capacity

\begin{tabular}{|c|c|c|}
\hline \multicolumn{3}{|c|}{$\begin{aligned} \text { Model (2): } R_{i t}= & \beta_{0}+\beta_{1} N P P S_{i t}+\beta_{2} B V E P S_{i t}+\delta_{1} D_{i t}^{I F R S}+ \\
& \delta_{2} D_{i t}^{I F R S} \times N P P S_{i t}+\varepsilon_{i t}\end{aligned}$} \\
\hline & Coeff. & $T$ Test \\
\hline Intercept & 0.0507 & $14.1105^{* * *}$ \\
\hline $\mathrm{NPPS}_{i t}$ & 0.0061 & $3.7186^{* * *}$ \\
\hline BVEPS $_{i t}$ & -0.0001 & $-2.3416^{* *}$ \\
\hline$D_{i t}^{I F R S}$ & -0.0655 & $-13.0374 * * *$ \\
\hline$D_{i t}^{1 \text { FRS }} x$ NPPS $_{i t}$ & 0.0087 & $2.9256^{* * *}$ \\
\hline$R^{2}$ (adj.) & \multicolumn{2}{|c|}{$0.0209(0.0204)$} \\
\hline$F$ Test & \multicolumn{2}{|c|}{$50.9628^{* * *}$} \\
\hline Chow (Obs.) & \multicolumn{2}{|c|}{$122.5880^{* * *}(5.787)$} \\
\hline DGI & \multicolumn{2}{|c|}{$1.1236^{*}$} \\
\hline Hausman & \multicolumn{2}{|c|}{2.8740} \\
\hline No. Obs. & \multicolumn{2}{|c|}{9.558} \\
\hline
\end{tabular}

Estimation performed using the random effects model. $R_{i t}$ is the return of the $i$-th share in quarter $t$, calculated logarithmically. NPPS ${ }_{i t}$ represents the net profit of the exercise per share of the $i$-th company in quarter $t$. BVEPS $i t$ is the book value of equity per share of the $i$-th company in quarter $t . D_{i t}^{\text {IFRS }}$ is a dummy variable. $D_{i t}^{\mathrm{IFRS}}=1$ if $t$ postdates 2007. In the Chow test, (obs.) represents the observation where the greatest magnitude was identified. No presence of multicollinearity was detected. Variance Inflation Factor (VIF) $<2$.

$*, * *$, and $* * *$ represent significance at $10 \%, 5 \%$, and $1 \%$, respectively.

Similar to the Model (1) estimation, the pooled regression revealed the occurrence of structural breaks at various times, as shown in Figure 2. However, the most significant occurrence was observed in the 4th quarter of 2008, for which the Chow test indicated an $F$ statistic equal to 122.5880 .

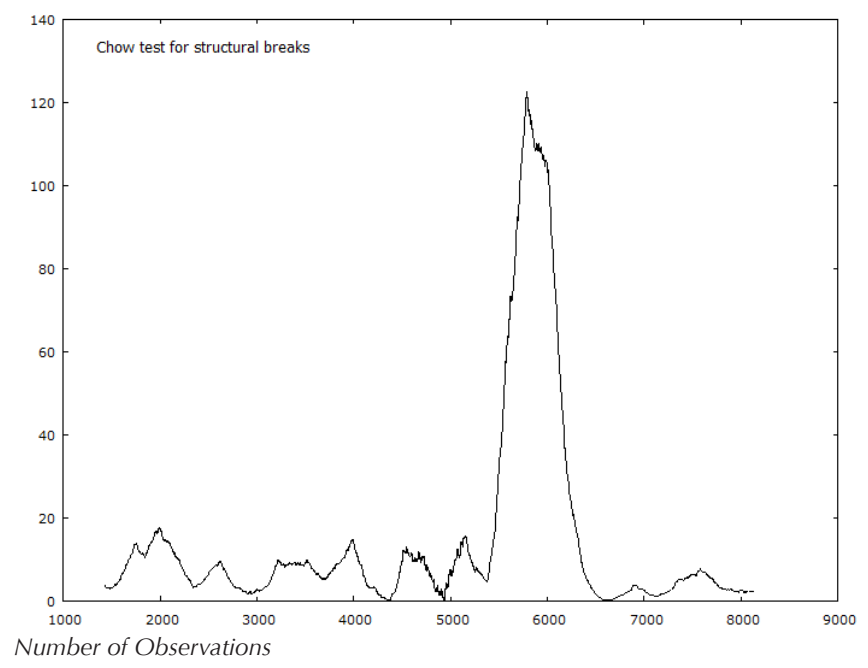

Figure 2

Chow Test Pattern - Model (2) Estimation

The displacement of the time of the greatest structural break in the pre-IFRS period is observed, as assessed in the previous model, to the period subsequent to that event, which results from the greater control exercised by introducing the dummy variable.

The modeling of panel data using the random effects model was more suitable for the data distribution accor- ding to the Chow and Hausman tests. This estimation showed better results than those assessed using Model (1). The NPPS ${ }_{i t}$ was significant in the relationship proposed. The model had a highly significant fit and greater explanatory power.

The parameters associated with the variables $D^{\mathrm{IFRS}}$ and $D^{\mathrm{IFRS}} x$ NPPS $_{i t}$ were highly significant, and the latter had a positive sign, as expected. These findings indicate that the periods of transition and of full adoption of the IFRS and the respective NPPS ${ }_{i t}$ were significant in explaining the variations in $R_{i t}$. This result corroborates the result found using Model (1), estimated based on temporal segregation.

Model (3) was estimated to assess the yearly effect of IFRS adoption, and the results are shown below:

Table 3

Model (3) Results - Associative Capacity

\begin{tabular}{|c|c|c|}
\hline \multicolumn{3}{|c|}{ Model (3): $R_{i t}=\beta_{0}+\beta_{1} N P P S_{i t}+\beta_{2}$ BVEPS $_{i t}+\sum_{\tau=1}^{6} \delta_{\tau} D_{i t}^{2007+\tau}+$} \\
\hline & Coeff. & $t$ Test \\
\hline Intercept & 0.0527 & $19.0325^{* * *}$ \\
\hline $\operatorname{NPPS}_{i t}$ & 0.0056 & $2.1352^{* *}$ \\
\hline BVEPS $_{i t}$ & -0.0002 & $-2.1469 * *$ \\
\hline$D_{i t}^{2008}$ & -0.2082 & $-25.1652^{* * *}$ \\
\hline$D_{i t}^{2009}$ & 0.0758 & $8.9609 * * *$ \\
\hline$D_{i t}^{2010}$ & -0.0296 & $-3.9638^{* * *}$ \\
\hline$D_{i t}^{2011}$ & -0.1151 & $-15.6283^{* * *}$ \\
\hline$D_{i t}^{2012}$ & -0.0582 & $-7.4270^{* * *}$ \\
\hline$D_{i t}^{2013}$ & -0.0863 & $-6.4863 * * *$ \\
\hline$D_{i t}^{2008} \times \mathrm{NPPS}_{i t}$ & 0.0062 & 1.3050 \\
\hline$D_{i t}^{2009} \times$ NPPS $_{i t}$ & 0.0071 & 1.1417 \\
\hline$D_{i t}^{2010} \times$ NPPS $_{i t}$ & -0.0059 & -0.9943 \\
\hline$D_{i t}^{2011} \times \mathrm{NPPS}_{i t}$ & 0.0120 & $2.5612^{* *}$ \\
\hline$D_{i t}^{2012} \times$ NPPS $_{i t}$ & 0.0172 & $2.7425^{* * *}$ \\
\hline$D_{i t}^{2013} \times \mathrm{NPPS}_{i t}$ & 0.0253 & $2.2336^{* *}$ \\
\hline$R^{2}$ (adj.) & & 391) \\
\hline$F$ Test & & \\
\hline Chow (Obs.) & & 82) \\
\hline DGI & & \\
\hline Hausman & & \\
\hline No. Obs. & & \\
\hline
\end{tabular}

Estimation performed using the random effects model. $R_{i t}$ is the return of the $i$-th share in quarter $t$, calculated logarithmically. NPPS it represents the net profit of the exercise per share of the $i$-th company in quarter $t$. BVEPS is the book value of equity per share of the $i$-th company in quarter $t$. $D_{i t}^{2009 \ldots 2013}$ are dummy variables. $D_{i t}^{2008 \ldots 2013}=1$ if $t$ is the year indicated. In the Chow test, (obs.) represents the observation where the greatest magnitude of the test was identified. No presence of multicollinearity was detected. Variance Inflation Factor $($ VIF $)<2$.

$*, * *$, and $* * *$ represent significance at $10 \%, 5 \%$, and $1 \%$, respectively.

Numerous structural break occurrences were found in the model that were not necessarily linked to the adoption of the IFRS, as already observed in previous models. 
However, the indication of a significantly more pronounced structural break occurred in the $3^{\text {rd }}$ quarter of 2008 (Chow test 59.9255), which is illustrated in Figure 3.

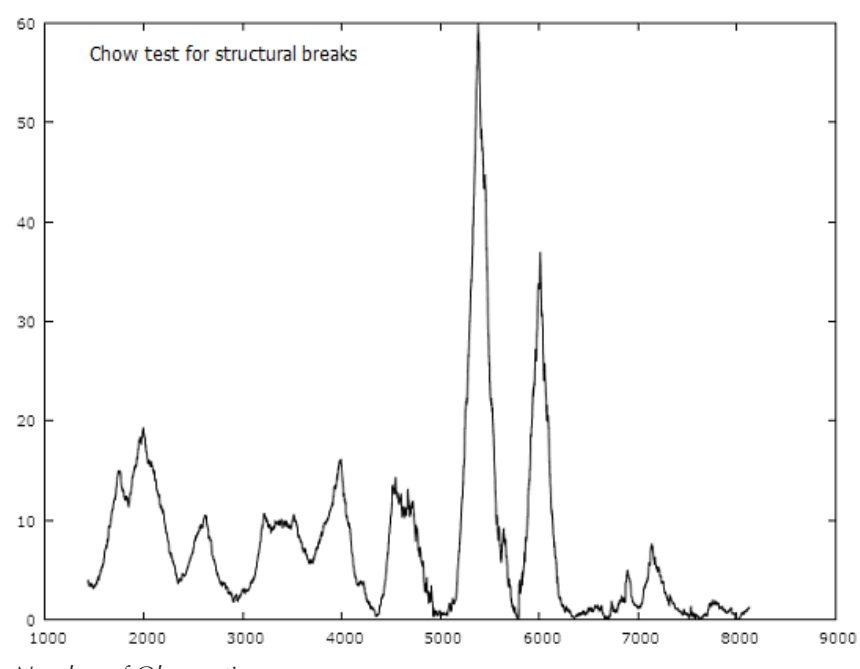

Number of Observations

Figure 3 Chow Test Pattern - Model (3) Estimation

The panel data method was again used, specifically the fixed effects model, given the indication of its adequacy by the Hausman test. The NPPS ${ }_{i t}$ coefficient was highly significant and had the expected sign. The coefficients of the dummy variables had statistical significances lower than $1 \%$. However, except for 2009, these coefficients were negative, contrary to the prediction. Conversely, significant coefficients for the multiplicative variables were only observed for 2011,2012, and 2013 at $5 \%, 1 \%$, and $5 \%$ significance levels, respectively. The signs of these coefficients are consistent with the predictions.

The estimation exhibited better fit and explanatory power than Models (1) and (2), suggesting that the greater control of the temporal effects in the transition and post-IFRS years improved the association. However, the presence of cross-sectional fixed effects was observed, thus requiring estimation using the fixed effects model. This characteristic was also observed in the Model (1) estimation for the post-IFRS period.

The results for 2008 and subsequent years provided some level of explanation for the $R_{i t}$ variations. However, the explanation only showed some connection to the effects of adopting the IFRS on the NPPS ${ }_{i t}$ for 2011 to 2013. This result suggests the existence of temporal effects that are not necessarily linked to the adoption of IFRS.

It is important to note that the adoption of the IFRS in Brazil coincided with the onset of the global financial crisis, which generated systemic effects on the market value of companies, precluding them from accurately expressing the consensus of market participants regarding expectations of future cash flows.

Thus, the negative and significant relationship observed for the dummy variables during the transition and
post-IFRS periods may reflect the financial crisis because the average returns for most of those years were lower than the average for the pre-IFRS period. Similarly, the marked structural breaks observed in the $3^{\text {rd }}$ quarter 2007 and especially in the $3^{\text {rd }}$ and $4^{\text {th }}$ quarters of 2008 may also have resulted from the effects of the financial crisis and not from the adoption of IFRS. A lack of statistical significance in the NPPS ${ }_{i t}$ coefficients is observed for 2008, 2009 , and 2010, suggesting that the NPPS ${ }_{i t}$ was not associated with $R_{i t}$ in those years.

The above findings are contrary to the results from Model (1), specifically regarding the transition period. These results allow us to conclude that the increased magnitude and significance of the NPPS ${ }_{i t}$ observed in the transition period did not result from the adoption of IFRS but rather from unidentified factors, albeit specific to NPPS ${ }_{i t}$ and not necessarily linked to occurrences during the transition and post-IFRS periods. This conclusion is supported by the statistical significance of coefficient $\beta_{1}$ observed in all of the models.

Regarding the period from 2011 to 2013, the beginning of the restoration of significance of the association between NPPS ${ }_{i t}$ and $R_{i t}$ was observed in 2011, and significance was fully restored starting in 2012, when a highly significant association was again observed. The failure to fully adopt the IFRS until 2010, pursuant to CVM Instruction No. 457/2007, amended by CVM Instruction No. $485 / 2010$, and the issuance or revision of several technical pronouncements starting in 2009 are the best possible explanations for these findings. Therefore, the period from 2008 to 2010 may in fact have represented a transition period, and the situation could have reversed starting in 2011.

It is worth highlighting that the low magnitude and lack of statistical significance of the NPPS ${ }_{i t}$ found in 2010 may explain the decrease of the NPPS ${ }_{i t}$ coefficient observed in the Model (1) estimation for the post-IFRS period, given the explanation above.

Finally, the results mostly indicate that the IFRS improved the associative capacity of the NPPS ${ }_{i t}$, thereby precluding the rejection of hypothesis $H 1$. That finding corroborates the results found in the literature and specifically the results reported by Barth et al. (2008), Lima (2010), Costa (2012), and Macedo et al. (2013).

\subsection{Information Timeliness}

In the first stage of the analysis of the effects of adopting the IFRS on the timeliness of accounting profits, Model (4) was estimated for both the total period and the IFRS adoption period, as shown in Table 4.

The most adequate panel model for the total period was the fixed effects model, which showed satisfactory fit and explanatory power higher than $37 \%$, which may be considered a good level of explanation for this type of relationship. The $R_{i t}$ coefficient showed low significance, suggesting that the accounting profit, on average, was not timely throughout the period. 


\begin{tabular}{|c|c|c|c|c|c|c|c|c|}
\hline \multicolumn{9}{|c|}{ Model (4): $\frac{N P P S_{i t}}{p_{t-1}}=\beta_{0}+\beta_{1} R_{i t}+\varepsilon_{i t}$} \\
\hline \multirow{2}{*}{ Period } & \multicolumn{2}{|c|}{$1 / 1999-1 / 2013$} & \multicolumn{2}{|c|}{$1 / 1999-4 / 2007$} & \multicolumn{2}{|c|}{$1 / 2008-4 / 2009$} & \multicolumn{2}{|c|}{$1 / 2010-1 / 2013$} \\
\hline & \multicolumn{2}{|c|}{ Total Period } & \multicolumn{2}{|c|}{ Pre-IFRS } & \multicolumn{2}{|c|}{ Transition } & \multicolumn{2}{|c|}{ Post-IFRS } \\
\hline \multirow[t]{2}{*}{ Panel Model } & \multicolumn{2}{|c|}{ Fixed Effects } & \multicolumn{2}{|c|}{ Random Effects } & \multicolumn{2}{|c|}{ Fixed Effects } & \multicolumn{2}{|c|}{ Fixed Effects } \\
\hline & Coeff. & $t$ Test & Coeff. & $t$ Test & Coeff. & $t$ Test & Coeff. & $t$ Test \\
\hline Intercept & -0.0866 & $-15.3300^{* * *}$ & $\begin{array}{c}- \\
0.1578\end{array}$ & $\begin{array}{c}- \\
3844^{* * *}\end{array}$ & $\begin{array}{c}- \\
0.0704\end{array}$ & $\begin{array}{c}- \\
124.0451^{* * *}\end{array}$ & $\begin{array}{c}- \\
0.0377\end{array}$ & $\begin{array}{c}- \\
68.3835^{* * *}\end{array}$ \\
\hline$R_{i t}$ & -0.0691 & $-1.8380 *$ & $\begin{array}{c}- \\
0.1069\end{array}$ & $\begin{array}{c}- \\
2.8298^{* * *} \\
\end{array}$ & $\begin{array}{c}- \\
0.0374\end{array}$ & -0.7956 & 0.0120 & 0.3340 \\
\hline$R^{2}$ (adj.) & \multicolumn{2}{|c|}{$0.3932(0.3773)$} & \multicolumn{2}{|c|}{$0.0000(0.0002)$} & \multicolumn{2}{|c|}{$0.7164(0.6713)$} & \multicolumn{2}{|c|}{$0.7653(0.7438)$} \\
\hline$F$ Test & \multicolumn{2}{|c|}{$24.6613^{* * *}$} & \multicolumn{2}{|c|}{-} & \multicolumn{2}{|c|}{$15.9091^{* * *}$} & \multicolumn{2}{|c|}{$35.6843^{* * *}$} \\
\hline $\begin{array}{l}\text { Chow } \\
\text { (Obs.) }\end{array}$ & \multicolumn{2}{|c|}{$\begin{array}{c}17.6892^{* * *} \\
(4.313)\end{array}$} & \multicolumn{2}{|c|}{$\begin{array}{c}3.9795^{* * *} \\
(876)\end{array}$} & \multicolumn{2}{|c|}{$\begin{array}{l}1.4415 \\
(1.037)\end{array}$} & \multicolumn{2}{|c|}{$\begin{array}{c}36.2557^{* * *} \\
(496)\end{array}$} \\
\hline Hausman & \multicolumn{2}{|c|}{$31.7853^{* * *}$} & \multicolumn{2}{|c|}{$3.6284^{*}$} & \multicolumn{2}{|c|}{$14.7414^{* * *}$} & \multicolumn{2}{|c|}{$5.1710^{* *}$} \\
\hline No. Obs & & 490 & & & & 738 & & 68 \\
\hline
\end{tabular}

$\underline{N P P S_{i t}}$

$\frac{p_{t-1}}{i t}$ is the net profit of the exercise per share of the $i$-th company in quarter $t$, deflated by the share price at the end of quarter $t$ - 1 . $R_{i t}$ is the return of the $i$-th share in quarter $t$, calculated logarithmically. In the Chow test, (obs.) represents the observation where the greatest magnitude of the test was identified. $*, * *$, and $* * *$ represent significance at $10 \%, 5 \%$, and $1 \%$, respectively.

However, the segregated analysis showed that this conclusion is not necessarily true. Although the estimates for the transition and post-IFRS periods showed high explanatory power, the significance of the $R_{i t}$ coefficient could not be assessed in the pre-IFRS period. Further details are provided below in the analysis of Model (6).

Table 5 shows the results from the estimations of Mo- dels (5) and (6).

Model (5) has an explanatory power higher than 37\% and a highly significant fit. However, no signs of timeliness were found in this case because none of the coefficients of the independent variables was significant. Thus, the introduction of dummy variables did not reveal any additional aspects.

Table $5 \quad$ Model (5) and (6) Results - Timeliness

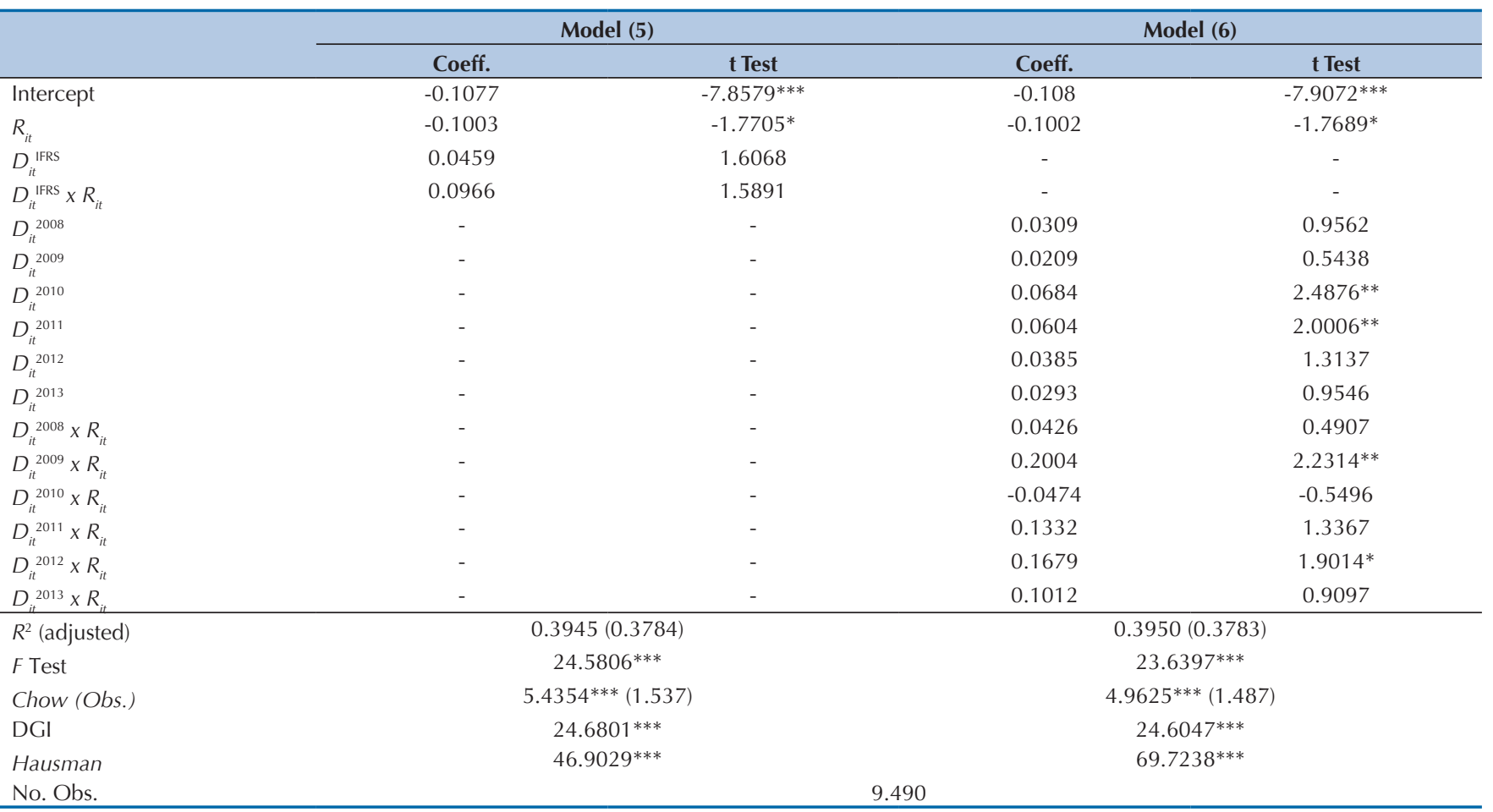

\footnotetext{
Estimation performed using the fixed effects model. $\frac{N P P S_{i t}}{p_{t-1}}$ is the net profit of the exercise per share of the $i$-th company in quarter $t$, deflated by the share price at the end of quarter $t-1 . R_{i t}$ is the return of the $i$-th share in quarter $t$, calculated in logarithmic form. $D_{i t}^{\text {IFRS }}$ is a dummy variable. $D_{i t}^{\text {IFRS }}=1$ if $t$ postdates the adoption of IFRS. $D_{i t}^{2009 \ldots 2013}$ are dummy variables. $D_{i t}^{2008 \ldots 2013}=1$ if $t$ is the indicated year.

In the Chow test, (obs.) represents the observation where the greatest magnitude of the test was identified.

No presence of multicollinearity was detected. Variance Inflation Factors (VIF) $<2$.

$*, * *$, and $* * *$ represent significance at $10 \%, 5 \%$, and $1 \%$, respectively.
} 
Conversely, Model (6) shows the existence of temporal effects in 2010 and 2011, which may explain part of $N P P S_{i t}$

the $\overline{p_{t-1}}$ variations, but they are not related to the $R_{i t}$ variations, that is, they do not express them.

In turn, $R_{i t}$ showed a significant association with $\frac{N P P S_{i t}}{p_{t-1}}$ in 2009. There is no apparent explanation for this specific result. In principle, no event specific to 2009 or possibly predating it would have been able to affect the timeliness of accounting profits exclusively in that year.
In combination, the results indicate that adopting the IFRS failed to improve the timeliness of accounting profits. On the contrary, the existing evidence shows a decrease in timeliness during the adoption period, thus requiring the rejection of hypothesis $H 2$.

\subsection{Conservatism}

The Model (7) estimation was based on the total period $(1 / 1999-1 / 2013)$ and the pre-IFRS - from 1/1999 to $4 / 2007$ - and post-IFRS - from $1 / 2008$ to $1 / 2013$ - periods. Table 6 presents the results.

\begin{tabular}{|c|c|c|c|c|c|c|c|c|}
\hline \multirow{4}{*}{$\begin{array}{c}\text { Model (7): } \\
\text { Period }\end{array}$} & \multicolumn{8}{|c|}{$\frac{N P P S_{i t}}{p_{t-1}}=\beta_{0}+\beta_{1} R_{i t}+\delta_{1} D R_{i t}+\delta_{2} D R_{i t} \times R_{i t}+\varepsilon_{i t}$} \\
\hline & \multicolumn{2}{|c|}{$1 / 1999-1 / 2013$} & \multicolumn{2}{|c|}{$1 / 1999-4 / 2007$} & \multicolumn{2}{|c|}{$1 / 2008-4 / 2009$} & \multicolumn{2}{|c|}{$1 / 2010-1 / 2013$} \\
\hline & \multicolumn{2}{|c|}{ Total Period } & \multicolumn{2}{|c|}{ Pre-IFRS } & \multicolumn{2}{|c|}{ Transition } & \multicolumn{2}{|c|}{ Post-IFRS } \\
\hline & Coeff. & $t$ Test & Coeff. & $t$ Test & Coeff. & $t$ Test & Coeff. & $t$ Test \\
\hline Intercept & $\begin{array}{c}- \\
0.0692\end{array}$ & $-5.0397^{* * *}$ & $\begin{array}{c}- \\
0.1123\end{array}$ & $\begin{array}{c}- \\
5.2460^{* * *}\end{array}$ & $\begin{array}{c}- \\
0.0660\end{array}$ & $\begin{array}{c}- \\
5.2252^{* * *}\end{array}$ & -0.0222 & $-2.1205^{* *}$ \\
\hline$R_{i t}$ & $\begin{array}{c}- \\
0.1241\end{array}$ & -1.5374 & $\begin{array}{c}- \\
0.0975\end{array}$ & -0.9114 & $\begin{array}{c}- \\
0.0077\end{array}$ & -0.1289 & -0.1033 & -1.1210 \\
\hline$D R_{i t}$ & $\begin{array}{c}- \\
0.0243\end{array}$ & -1.3400 & $\begin{array}{c}- \\
0.0487\end{array}$ & -1.3868 & $\begin{array}{c}- \\
0.0468\end{array}$ & $-2.0235^{* *}$ & 0.0003 & 0.0315 \\
\hline$D R_{i t} x R_{i t}$ & 0.0505 & 0.4732 & $\begin{array}{c}- \\
0.2207 \\
\end{array}$ & -1.2608 & $\begin{array}{c}- \\
0.1783 \\
\end{array}$ & -1.4879 & 0.2237 & $2.3354^{* * *}$ \\
\hline$R^{2}$ (adjusted) & \multicolumn{2}{|c|}{$0.3928(0.3767)$} & \multicolumn{2}{|c|}{$0.4474(0.4188)$} & \multicolumn{2}{|c|}{$0.7175(0.6723)$} & \multicolumn{2}{|c|}{$0.7666(0.7451)$} \\
\hline$F$ Test & \multicolumn{2}{|c|}{$24.4028^{* * *}$} & \multicolumn{2}{|c|}{$15.6552^{* * *}$} & \multicolumn{2}{|c|}{$15.8465^{* * *}$} & \multicolumn{2}{|c|}{$35.6246^{* * *}$} \\
\hline $\begin{array}{l}\text { Chow } \\
\text { (Obs.) }\end{array}$ & \multicolumn{2}{|c|}{$\begin{array}{c}8.9877^{* * *} \\
(4.296)\end{array}$} & \multicolumn{2}{|c|}{$\begin{array}{c}3.5214^{* * *} \\
(1.537)\end{array}$} & \multicolumn{2}{|c|}{$\begin{array}{c}1.7306 \\
(826)\end{array}$} & \multicolumn{2}{|c|}{$\begin{array}{c}20.8710^{* * *} \\
(459)\end{array}$} \\
\hline DGI & \multicolumn{2}{|c|}{$24.2686^{* * *}$} & & $5 * * *$ & & *** & & *** \\
\hline Hausman & & $5 * * *$ & & $5 * * *$ & & F*** & & $* * *$ \\
\hline No. Obs & & & & & & & & \\
\hline$R_{i t}>=0$ & & & & & & & & \\
\hline$R_{i t}<0$ & & & & & & & & \\
\hline
\end{tabular}

All estimations were performed using the fixed effects model. $\frac{N P P S_{i t}}{p_{t-1}}$ is the net profit of the exercise per share of the $i$-th company in quarter $t$, deflated by the share price at the end of quarter $t-1 . R_{i t}$ is the return of the $i$-th share in quarter $t$, calculated in logarithmic form. $D R_{i t}$ is a dummy variable. $D R_{i t}=1$ if $R_{i t}<0$. In the Chow test, (obs.) represents the observation where the greatest magnitude of the test was identified. No presence of multicollinearity was detected. Variance Inflation Factors $($ VIF $)<3$.

$*, * *$, and $* * *$ represent significance at $10 \%, 5 \%$, and $1 \%$, respectively.

The model shows a highly significant fit and a good explanatory power of approximately $37 \%$ for the total period. However, no signs of conditional conservatism are found for the total period, given the non-significance of the coefficient $D R_{i t} x R_{i t}$, which was also observed in the pre-IFRS and transition periods.

The estimation for the post-IFRS period shows similar characteristics to the total period. However, the model's explanatory power was higher than $74 \%$, which is considered high. A comparison between these results and those assessed in the timeliness analysis - Model (4) - indicates that the control of negative returns enabled by the dummy va- riables accounts for the increase of this explanatory power.

These results indicate the importance of negative returns in the studied relationship. Moreover, reinforcing this interpretation, the $D R_{i t} x R_{i t}$ coefficient is highly significant, suggesting that the adoption of IFRS increased the level of conditional conservatism of accounting profits when considering the pre-IFRS and transition periods.

The results shown in Table 7 were obtained when controlling the pre-IFRS, transition, and post-IFRS periods in a single model, as well as each year of the post-IFRS period. 
Model (8) and (9) Results - Conservatism

\begin{tabular}{|c|c|c|c|c|c|}
\hline & \multicolumn{2}{|c|}{ Model (8) } & \multicolumn{3}{|c|}{ Model (9) } \\
\hline & Coeff. & $t$ Test & & Coeff. & $t$ Test \\
\hline Intercept & -0.0692 & $-5.0396^{* * *}$ & & -0.0692 & $-5.0328^{* * *}$ \\
\hline$R_{i t}$ & -0.1244 & -1.5396 & & -0.1244 & -1.5382 \\
\hline$D R_{i t}$ & -0.0524 & $-2.0363^{* *}$ & & -0.0526 & $-2.0457^{* *}$ \\
\hline$D R_{i t} \times R_{i t}$ & 0.0028 & 0.0188 & & 0.0034 & 0.0227 \\
\hline$D_{i t}^{I F R S} \times D R_{i t}$ & 0.0544 & 1.6256 & & - & - \\
\hline$D_{i t}{ }^{\mathrm{IFRS}} \times D R_{i t} \times R_{i t}$ & 0.0942 & 0.7353 & & - & - \\
\hline$D_{i t}^{2008} \times D R_{i t}$ & - & - & & 0.0177 & 0.5396 \\
\hline$D_{i t}{ }^{2009} \times D R_{i t}$ & - & - & & 0.004 & 0.0524 \\
\hline$D_{i t}^{2010} \times D R_{i t}$ & - & - & & 0.0817 & $2.4636^{* *}$ \\
\hline$D_{i t}{ }^{2012} \times D R_{i t}$ & - & - & & 0.0623 & $1.9635^{* *}$ \\
\hline$D_{i t}^{2013} \times D R_{i t}$ & - & - & & 0.0562 & 1.3345 \\
\hline$D_{i t}^{2008} \times D R_{i t} \times R_{i t}$ & - & - & & 0.0041 & 0.0303 \\
\hline$D_{i t}{ }^{2009} \times D R_{i t} \times R_{i t}$ & - & - & & 0.048 & 0.1858 \\
\hline$D_{i t}{ }^{2010} \times D R_{i t} \times R_{i t}$ & - & - & & 0.0008 & 0.0051 \\
\hline$D_{i t}^{2011} \times D R_{i t} \times R_{i t}$ & - & - & & 0.1373 & 0.8779 \\
\hline$D_{i t}^{2012} \times D R_{i t} \times R_{i t}$ & - & - & & 0.2086 & 1.2146 \\
\hline$D_{i t}^{2013} \times D R_{i t} \times R_{i t}$ & - & - & & 0.1949 & 0.9963 \\
\hline$R^{2}$ (adjusted) & & & & & \\
\hline$F$ Test & & & & & \\
\hline DGI & & & & & \\
\hline Hausman & & & & & \\
\hline No. Obs. & & & 9.488 & & \\
\hline
\end{tabular}

\section{$\underline{N P P S_{i t}}$}

The estimations were performed using the fixed effects model. $\overline{p_{t-1}}$ is the net profit from the exercise per share of the $i$-th company in quarter $t$, deflated by the share price at the end of quarter $t-1 . R_{i t}$ is the return of the $i$-th share in quarter $t$, calculated in logarithmic form. $D R_{i t}$ is a dummy variable. $D R_{i t}=1$ if $R_{i t}$ $<0 . D_{i t}^{\text {IFRS }}$ is a dummy variable. $D_{i t}^{\text {IFRS }}=1$ if $t$ postdates the adoption of IFRS. $D_{i t}^{2009 \ldots 2013}$ are dummy variables. . $D_{i t}^{2008 \ldots 2013}=1$ if $t$ is the indicated year.

In the Chow test, (obs.) represents the observation where the greatest magnitude of the test was identified. No presence of multicollinearity was detected. Variance Inflation Factors (VIF) $<5$.

$*, * *$, and $* * *$ represent significance at $10 \%, 5 \%$, and $1 \%$, respectively.

Satisfactory fit and an explanatory power higher than $37 \%$ is observed in the estimations. However, none of the models show significant coefficients of variables that are indicative of the presence of conditional conservatism, either before or after adopting the IFRS, which contradicts the result obtained using Model (7) for the post-IFRS period and confirms the initial indication of an increased level of conditional conservatism of accounting profits in this period.

Considering the results obtained using Models (7), (8), and (9), hypothesis H3 is rejected, which corroborates the findings of Santos et al. (2011), Paulo, Cavalcante, and Melo (2012), and Rodrigues (2012).

Conversely, some of these results contradict the findings of a series of studies conducted in Brazil, including those of Costa, Costa, and Lopes (2006), Coelho and Lima (2007), Santos and Costa (2008), and Almeida, Scalzer, and Costa (2008). However, the existing methodological differences, including the statistical methods used, sample sizes, and periods, among others, are aspects that should be considered.

Finally, two other issues also merit comment: (1) periods with negative returns were significant $\left(D R_{i t}=1\right)$; and (2) the models showed high explanatory power.

The representativity of the periods when negative returns were observed may suggest the occurrence of events not associated with the negative variations of prices and unrelated to accounting profits in the ratio of these variations. Interestingly, the results show that these events were not linked to the adoption of IFRS because the variables representing the interactions between $D R_{i t}, R_{i t}$, and the dummy variables indicative of this period were not significant.

The high explanatory power shown by the models is atypical when considering domestic studies as well as the seminal study by Basu (1997). However, the use of a model that was more appropriate to the characteristics of the data, namely, the fixed effects model, significantly improved the 
adjusted $R^{2}$ of models. For example, the estimations of Models (7), (8), and (9) using pooled regression based on the period from $1 / 1999$ to $1 / 2013$ showed adjusted $R^{2}$ values of $0.0066,0.0086$, and 0.0082 , respectively, versus 0.3767 , 0.3770 , and 0.3767 , respectively, that were found when the estimations were performed using the fixed effects model.

\section{FINAL CONSIDERATIONS}

The present study aimed to assess the effects of the mandatory adoption of the IFRS on the information relevance of accounting profits for participants in the Brazilian stock market. This relevance is represented by the following dimensions: (i) associative capacity with share prices; and (ii) information timeliness. Furthermore, the conservatism level was assessed in the timeliness analysis.

The results indicated that adopting the IFRS increased the associative capacity of accounting profits (non-rejection of H1), which corroborates the evidence reported in the domestic and international literature. The results regarding timeliness suggested that adopting the IFRS caused a decline in timeliness (rejection of $\mathrm{H2}$ ). Finally, the adoption of IFRS had no effect on the level of conditional conservatism (rejection of $H 3$ ).

The results regarding timeliness indicate that accounting profits showed signs of timeliness before the adoption of the IFRS that could not be identified in subsequent periods. This finding is puzzling because although the assumption of competence is a characteristic present in both the domestic and IFRS standards, the latter tend to generate timelier information because they are less objectively guided toward the recognition and measurement of a company's assets and liabilities and performance. This observation merits an in-depth analysis.

The results regarding conservatism corroborated the findings of Santos et al. (2011) and Rodrigues (2012), although the finding that this attribute was absent in the pre-IFRS period differs from other studies. This field of study merits examination beyond the descriptive nature of the econometric models used, which is the typical approach of research studies. Further understanding of this phenomenon is necessary to assess more fundamental issues related to accounting standards and the profile of Brazilian stock market investors from an explanatory standpoint.

Jointly, these results suggest that adopting the IFRS failed to increase the information relevance of accoun- ting profits for market participants. In principle, this finding contradicts the fundamental purpose of those standards: to provide useful information for investors' decision-making process.

On other hand, given that the associative capacity expresses the level of association between variations in company value and variations in accounting profits over time, the evidence shows that accounting profits at least tend to express what affected the company's value, albeit in an untimely manner. Therefore, the IFRS may presumably have improved the capacity of accounting profits to express what should be recognized from an investor's standpoint, which is a positive effect of adopting the IFRS.

Moreover, the finding that the absence of conditional conservatism may actually promote information quality and possibly its usefulness, rather than being detrimental to information quality as advocated by much of the literature, requires further analysis because the absence of that conservative bias contributes to information neutrality, thus enabling it to more reliably represent what it should express.

However, this study only included publicly traded companies, which represent only a portion of the various users of accounting information, and the study assumed that share pricing represents an unbiased response from market participants regarding company value. Interactions with legal, institutional, and political factors and their effects on the profit-return-IFRS relationship were not assessed. This approach represents a limitation when analyzing the more structural aspects of this relationship, although to some extent it is acceptable.

Another limitation of the study is the failure to control the effects of the global financial crisis. Furthermore, a lack of information content analysis limited the scope of the study because examining the market reaction to the disclosure of accounting profits could provide answers to questions regarding timeliness.

These and other aspects provide interesting research avenues that may provide a new understanding of the effects of adopting the IFRS in Brazil. 
Ahmed, K., Chalmers, K., \& Khlif, H. (2013). A meta-analysis of IFRS adoption effects. The International Journal of Accounting, 48 (2), 173-217.

Almeida, J. C. G., Scalzer, R. S., \& Costa, F. M. (2008). Níveis diferenciados de governança corporativa e graus de conservatism: estudo empírico em companhias abertas listadas na BOVESPA. Revista de Contabilidade e Organizações - FEA-RP/USP, São Paulo,'2 (2), 118-131.

Arellano, M. (2003). Panel data econometrics. Oxford: Oxford University Press.

Ashbaugh, H., \& Pincus, M. (2001). Domestic accounting standards, international accounting standards, and the predictability of earnings. Journal of Accounting Research, 39 (3), 417-434.

Ball, R. (2006). International financial reporting standards (IFRS): pros and cons for investors. Accounting and Business Research, 36 (supplement 1, special issue: International Accounting Policy Forum), 5-27.

Barth, M. E., Beaver, W. H., \& Landsman, W. R. (2001). The relevance of the value relevance literature for financial accounting standard setting another view. Journal of Accounting and Economics, 31 (1-3), 77-104.

Barth, M. E, \& Clinch, G. (2009). Scale effects in capital markets-based accounting research. Journal of Business Finance \& Accounting, 36 (3-4), 253-288

Barth, M. E., \& Kallapur, S. (1996). The effects of cross-sectional scale differences on regression results in empirical accounting research: Contemporary Accounting Research, 13 (2), 527-567.

Barth, M. E., Landsman, W. R., \& Lang, M. H. (2008). International accounting standards and accounting quality. Journal of Accounting Research, 46 (3), 467-498.

Basu, S. (1997). The conservatism principle and the asymmetric timeliness of earnings. Journal of Accounting and Economics, 24 (1), 3-37.

Beaver, W., Lambert, R., \& Morse, D. (1980). The information content of security prices. Journal of Accounting and Economics, 2 (1), 3-28.

Callao, S., Jarne, J. I., \& Laínez, J. A. (2007). Adoption of IFRS in Spain: effect on the comparability and relevance of financial reporting. Journal of International Accounting Auditing \& Taxation, 16, 148-178.

Clarkson, P., Hanna, J. D., Richardson, G. D., \& Thompson, R: (2011). The impact of IFRS adoption on the value relevance of book value and earnings. Working Paper. Recuperado em 20 fevereiro, 2013, de http:// ssrn.com/abstract=1614362.

Coelho, A. C., \& Lima, I. S. (2007). Information quality e conservatism nos resultados contábeis publicados no Brasil. Revista Contabilidade \& Finanças - USP, São Paulo, 18 (45), 38-49.

Costa, F. M., Costa, A. C. O., \& Lopes, A. B. (2006). Conservatism em cinco países da América do Sul. Revista Contabilidade \& Finanças USP, São Paulo, 17 (41), 7-20.

Costa, P. S. (2012). Implitcações da adoção das IFRS sobre a conformidade financeira e fiscal das companhias abertas brasileiras. Tese de doutorado, Universidade de São Paulo, São Paulo, SP, Brasil, 2012.

Dantas, J. A., Rodrigues, F. F., Niyama, J. K., \& Mendes, P. C. M. (2010) Normatização contábil baseada em princípios ou em regras? Benefícios, custos, oportunidades e riscos. Revista de Contabilidade e Organizações - FEA - RP/SP, 4 (9), 3-29.

Garanina, T. A., \& Kormiltseva, P. S. (2014). The effect of International Financial Reporting Standards (IFRS) adoption on the value relevance of financial reporting: a case of Russia. In C. N. Albu, \& R. V. Mustata (Ed.). Accounting in Central and Eastern Europe (Research in Accountịng in Emerging Economies, v. 13, Chap. 8, pp. 27-60), Emerald Group Publishing Limited.

Gil-Alana, L. A., Iniguez-Sanchez, R., \& Lopez-Espinosa, G. (2011). Endogenous problems in cross-sectional valuation models based on accounting information. Review of Quantitative Finance and Accounting, 37 (2), 245-265.
Hung, M., \& Subramanyam, K. R. (2007). Financial statement effects of adopting international accounting standards: the case of Germany. Review of Accounting Studies, 12 (4), 623-657.

Jarva, H., \& Lantto, A. M. (2012). Information content of IFRS versus domestic accounting standards: evidence from Finland. Working Paper. Recuperado em 06 julho, 2012, de http://ssrn.com/ abstract $=1588087$

Karampinis, N., \& Hevas, D. (2009). The effect of the mandatory application of IFRS on the value relevance do accounting data: some evidence from Greece. European Research Studies, XII (1), 73-100.

Kargin, S. (2013). The impact of IFRS on the value relevance of accounting information: evidence from Turkish firms. International Journal of Economics and Finance, 5 (4), 71-80.

Klimczak, K. M. (2011). Market reaction to mandatory IFRS adoption: evidence from Poland. Accounting and Management Information Systems, 10 (2), 228-248.

Landsman, W. R., Maydew, E. L., \& Thornock, J. R. (2012). The information content of annual earnings announcements and mandatory adoption of IFRS. Journal of Accounting and Economics, 53 (1-2), 34-54.

Leuz, C., \& Wysocki, P. (2008). Economic consequences of financial reporting and disclosure regulation: a review and suggestions for future research. Working Paper, University of Chicago.

Li, S. (2010). Does mandatory adoption of International Financial Reporting Standards in the European Union reduce the cost of equity capital? The Accounting Review, 85 (2), 607-636.

Lima, J. B. N. (2010): A relevância da accounting information e o processo de convergência para as normas IFRS no Brasil. Tese de doutorado, Universidade de São Paulo, São Paulo, SP, Brasil.

Macedo, M. A. S., Machado, M. R., Machado, M. A. V., \& Mendonça, P. H. C. (2013). Impacto da convergência às accounting standards internacionais no Brasil sobre o information content da Contabilidade. Revista de Educação e Pesquisa em Contabilidade, 7 (3), $222-239$

Niyama, J. K. (2007). Contabilidade internacional. São Paulo: Atlas.

Oliveira, V. A., \& Lemes, S. (2011). Nível de convergência dos princípios contábeis brasileiros e norte-americanos às normas do IASB: uma contribuição para a adoção das IFRS por empresas brasileiras. Revista Contabilidade \& Finanças, 22 (56), 155-173.:

Paulo, E., Cavalcante, P. R. N., \& Melo, I. I. S. L. (2012). Qualidade da accounting information na oferta pública de ações e debêntures pelas companhias abertas brasileiras. Brazilian Business Review - BBR, Vitória, 9 (1), 1-26.

Rodrigues, J. M. (2012). Convergência contábil internacional: uma análise da qualidade da accounting information em razão da adoção dos padrões internacionais de contabilidade editados pelo IASB. Tese de doutorado, Universidade de Brasília - UnB, Universidade Federal da Paraíba - UFPB, Universidade Federal do Rio Grande do Norte UFRN, Brasília, DF, Brasil.

Santos, L. P. G., Lima, G. A. S. F., Freitas, S. C., \& Lima, I. S. (2011). Efeito da Lei 11.638/07 sobre o conditional conservatism das empresas listadas BM\&FBOVESPA. Revista Contabilidade e Finanças - USP, São Paulo, 22 (56), 174-188.

Santos, L. S. R., \& Costa, F. M. (2008). Conservatism contábil e timeliness: evidências empíricas nas accounting statements de empresas brasileiras com ADRS negociados na Bolsa de Nova Iorque. Revista Contabilidade e Finanças - USP, São Paulo, 19 (48), 27-46.

Soderstrom, N. S., \& Sun, K. J. (2007). IFRS adoption and accounting quality: a review. European Accounting Review, 16 (4), 675-702. 